\title{
Peroxide Modulation of Slow Onset Potentiation in Rat Hippocampus
}

\author{
Jonathan M. Auerbach and Menahem Segal \\ Department of Neurobiology, The Weizmann Institute, Rehovot 76100, Israel
}

\begin{abstract}
Exposure of rat hippocampal slices to low concentrations of the muscarinic agonist carbachol (CCh) has been shown to produce a slow onset long-term potentiation (LTP) of reactivity to afferent stimulation in CA1 neurons. Although this potentiation shares a number of properties with tetanic LTP, muscarinic LTP $\left(L_{T P}\right)$ is independent of activation of the NMDA receptor. We now demonstrate that low levels of hydrogen peroxide $\left(\mathrm{H}_{2} \mathrm{O}_{2}\right)$ cause hippocampal slices to lose the ability to express LTP $_{m}$. This powerful effect of $\mathrm{H}_{2} \mathrm{O}_{2}$ is selective in that it does not affect the reactivity of hippocampal neurons to higher concentrations of CCh. In fact, $\mathrm{H}_{2} \mathrm{O}_{2}$ also blocks induction of a slow onset, non-NMDA-dependent tetanic LTP (NN-LTP). The functional relevance of this action of $\mathrm{H}_{2} \mathrm{O}_{2}$ is exemplified by the fact that
\end{abstract}

the hippocampus of aged rats, which produces higher levels of endogenous $\mathrm{H}_{2} \mathrm{O}_{2}$ than that of young rats, lacks LTP and expresses a markedly reduced NN-LTP. In aged rats, the lack of $\mathrm{LTP}_{\mathrm{m}}$ contrasts with an apparently normal muscarinic suppression of the EPSP slope induced by higher concentrations of $\mathrm{CCh}$. When hippocampal slices from aged animals are treated with catalase, an enzyme that breaks down $\mathrm{H}_{2} \mathrm{O}_{2}$, LTP $_{\mathrm{m}}$ is restored, and NN-LTP is enhanced. Thus, our study proposes a unique and novel age-dependent peroxide regulation of LTP $_{m}$ in the brain and provides a link between the cholinergic system, aging, and memory functions.

Key words: hippocampus; carbachol; aging; LTP; peroxides; catalase
Long-term potentiation (LTP), a long-lasting increase in the efficacy of synaptic transmission (Bliss and Lømo, 1973; Bliss and Collingridge, 1993), can be induced in pyramidal cells of area CA1 in the hippocampal slice by a brief, high-frequency tetanic stimulation of the Schaffer collateral and commissural fibers. This manner of LTP induction is dependent on the activation of NMDA receptors. LTP can also be induced in a non-NMDA-dependent manner by exposure of the slice to compounds that transiently increase cellular excitability (Aniksztejn and Ben-Ari, 1991; Bortolotto and Collingridge, 1993) or by repeated high-frequency tetani delivered in the presence of an NMDA antagonist (Grover and Teyler, 1990). LTP has been proposed as a cellular model of neuronal plasticity and is therefore used to study processes underlying plastic changes associated with learning and memory (Doyere and Laroche, 1992; Bliss and Collingridge, 1993).

Forebrain cholinergic neurons have been associated with cognitive functions of the brain (Buresova et al., 1964; Bartus et al., 1982). Cholinergic deficits have been found in aged, demented patients, and cholinergic drugs have been used to modulate memory in young rats (Bartus et al., 1982; Rossor, 1982; Coyle et al., 1983; Lebrun et al., 1990; Molchan et al., 1992). The search for the physiological actions of ACh may be of major importance for understanding the role of $\mathrm{ACh}$ in cognitive functions (Bartus et al., 1982; Segal, 1982a,b; Madison et al., 1987; Markram and Segal, 1992). Thus far, approximately a dozen effects of ACh on central neurons have been reported, but none is intuitively re-

Received May 15, 1997; revised Aug. 25, 1997; accepted Aug. 29, 1997.

We thank Drs. Y. Groner and Y. Zick for critical discussions.

Correspondence should be addressed to Menahem Segal, Department of Neurobiology, The Weizmann Institute, Rehovot 76100, Israel.

Dr. Auerbach's present address: Laboratory of Molecular Biology, National Institute of Neurological Disorders and Stroke, National Institutes of Health, Bethesda, MD 20897-4092.

Copyright (C) 1997 Society for Neuroscience $0270-6474 / 97 / 178695-07 \$ 05.00 / 0$ lated in any selective manner to LTP or to neuronal plasticity associated with cognitive functions of the brain.

We have discovered recently a gradually developing, longlasting potentiation induced by exposure of a hippocampal slice to a low concentration $(0.5 \mu \mathrm{M})$ of carbachol $(\mathrm{CCh})$ (Auerbach and Segal, 1994). This muscarinic LTP $\left(\mathrm{LTP}_{\mathrm{m}}\right)$ is mediated by an M2 muscarinic receptor and is independent of the activation of an NMDA receptor (Auerbach and Segal, 1996).

Among several agents that block the late onset of LTP, hydrogen peroxide $\left(\mathrm{H}_{2} \mathrm{O}_{2}\right)$ (Pellmar et al., 1991) is generated naturally in living cells, and has also been shown to interact with kinases and phosphatases involved in LTP. In the present study we replicated the results of Pellmar et al. (1991). In addition, we found that $\mathrm{LTP}_{\mathrm{m}}$ is totally lacking in slices prepared from aged rats and is blocked by low levels of exogenously $\mathrm{H}_{2} \mathrm{O}_{2}$ added to slices from young rats. This is a unique age dependency of $\mathrm{LTP}_{\mathrm{m}}$ induction, which is correlated with an increased rate of peroxide production in aged hippocampal slices. We thus establish a link between aging, cholinergic functions, and oxygen radicals in the brain.

\section{MATERIALS AND METHODS}

Hippocampal slices $(350 \mu \mathrm{m})$ were prepared from adult male Wistar rats obtained from a local breeding colony, and recordings were performed as described previously (Auerbach and Segal, 1996). Young rats were 7-10 weeks old, and aged rats were 24-30 months old. Experiments were performed in a submerged slice chamber, heated to $30-32^{\circ} \mathrm{C}$, and superfused at a rate of $2.5 \mathrm{ml} / \mathrm{min}$ with standard artificial CSF (ACSF), containing (in mM): $124 \mathrm{NaCl}, 4 \mathrm{KCl}, 26 \mathrm{NaHCO}_{3}, 1.25 \mathrm{NaH}_{2} \mathrm{PO}_{4}, 2$ $\mathrm{CaCl}_{2}, 2 \mathrm{MgSO}_{4}$, and 10 glucose, $\mathrm{pH}$ 7.4. The ACSF was saturated with a $95 \% \mathrm{O}_{2} / 5 \% \mathrm{CO}_{2}$ gas mixture (flow rate, $0.41 / \mathrm{min}$ ). A bipolar stainless steel stimulating electrode was placed in stratum radiatum of CA1. Test stimulation was delivered every $30 \mathrm{sec}, 50 \mu \mathrm{sec}$ pulse duration, with intensity adjusted such that evoked responses were approximately halfmaximal. The extracellular recording electrode, containing $2 \mathrm{M} \mathrm{NaCl}$ (2-4 $\mathrm{M} \Omega$ ), was placed in stratum radiatum of the CA1 region for recording of EPSPs. Drugs were applied via the superfusion medium 
beginning $10 \mathrm{~min}$ after the establishment of a stable baseline response. A drug-naive hippocampal slice was used in each experiment. Tetanic LTP was induced by delivering a $100 \mathrm{~Hz}, 1 \mathrm{sec}$ train through the stimulation electrode at twice the test stimulus intensity. Non-NMDA LTP $(\mathrm{NN}$ LTP) was induced by delivering three $1 \mathrm{sec}$ trains of $200 \mathrm{~Hz}$, separated by $3 \mathrm{~min}$ inter-train intervals in the presence of $25 \mu \mathrm{M}$ NMDA receptor antagonist DL-2-amino-5-phosphonovaleric acid (2-APV).

Stock solutions were prepared in distilled water and stored at $-20^{\circ} \mathrm{C}$ All working solutions were diluted in ACSF immediately before use. All drugs were obtained from Research Biochemicals (Natick, MA) except 2-APV $\mathrm{H}_{2} \mathrm{O}_{2}$, and catalase, which were obtained from Sigma. Signals were amplified with an Axoclamp-2A amplifier and digitized with a DMA interface (Axon Instruments, Foster City, CA). Data were collected, stored, and analyzed on an IBM-compatible computer (Asyst 3.1; Asyst Software Tech., Inc., Rochester, NY). Data were pooled and normalized with respect to the steady baseline values (baseline $=1.00)$ and expressed as the mean \pm SEM.

Endogenous hydrogen peroxide levels were determined using a variation of the method described by Cathcart et al. (1983). Briefly, 2,7dichlorofluorescein (DCF) was freshly prepared and incubated with slices at a final concentration of 2-5 $\mu \mathrm{M}$. Varying concentrations of $\mathrm{H}_{2} \mathrm{O}_{2}$ were added to blanks to construct a standard curve. The DCF and slices or known concentrations of $\mathrm{H}_{2} \mathrm{O}_{2}$ were incubated for $30-60 \mathrm{~min}$ at $37^{\circ} \mathrm{C}$. The medium was then removed, and its fluorescence was measured with a standard fluorescein filter set. Calibration curves were constructed for measurements in the presence and absence of slices and both for young and aged slices. A linear relation between $\mathrm{H}_{2} \mathrm{O}_{2}$ concentration and fluorescence was established.

\section{RESULTS}

CCh $(0.5 \mu \mathrm{M})$, perfused for a standard duration of $20 \mathrm{~min}$ at $30-32^{\circ} \mathrm{C}$, produced a slow onset, long-lasting potentiation of the slope of the population EPSP, recorded in stratum radiatum of the hippocampal area CA1. The EPSP slope increased to $\sim 60 \%$ above baseline seen here (Fig. $1 A$ ) and previously (Auerbach and Segal, 1994, 1996).

We studied the actions of $\mathrm{H}_{2} \mathrm{O}_{2}$ on $\mathrm{LTP}_{\mathrm{m}}$ by applying $0.0001 \%$ $(29 \mu \mathrm{M}) \mathrm{H}_{2} \mathrm{O}_{2}$ via the perfusion medium before and together with varying concentrations of $\mathrm{CCh}$. Addition of $\mathrm{H}_{2} \mathrm{O}_{2}$ by itself for 25 min followed by washout with normal medium did not affect the EPSP slope in recorded slices $(n=4$; Fig. 1$)$. However, $\operatorname{LTP}_{\mathrm{m}}$ produced by $0.5 \mu \mathrm{M} C \mathrm{Ch}$ was completely eliminated by $\mathrm{H}_{2} \mathrm{O}_{2}$ (Fig. $1 A$ ). In fact, instead of potentiation, a slight depression of the EPSP slope was seen on addition of $0.5 \mu \mathrm{M} \mathrm{CCh}$ in the presence of $\mathrm{H}_{2} \mathrm{O}_{2}$. This effect was selective in that $\mathrm{H}_{2} \mathrm{O}_{2}$ alone did not affect the EPSP slope, nor did it block the depression of the EPSP slope induced by higher concentrations $(5.0 \mu \mathrm{M})$ of $\mathrm{CCh}$ (Fig. $1 B$ ). Actually, this depression was slightly enhanced when $5.0 \mu \mathrm{M} C \mathrm{Ch}$ was added in the presence of $\mathrm{H}_{2} \mathrm{O}_{2}$. In addition, $\mathrm{H}_{2} \mathrm{O}_{2}$ together with $0.1 \mu \mathrm{M} \mathrm{CCh}$ had no effect on the EPSP slope, indicating that $\mathrm{H}_{2} \mathrm{O}_{2}$ did not act simply to sensitize the slice to $\mathrm{CCh}$ and change its dose-response characteristics (Fig. 1C).

Previously, $\mathrm{H}_{2} \mathrm{O}_{2}$ has been shown to reduce the late phase of tetanic LTP (Pellmar et al., 1991). Here, we confirm this result using $29 \mu \mathrm{M} \mathrm{H}_{2} \mathrm{O}_{2}$, a concentration lower than that previously used by Pellmar et al. (1991). $\mathrm{H}_{2} \mathrm{O}_{2}(29 \mu \mathrm{M})$ was applied via the perfusion medium beginning $10 \mathrm{~min}$ before tetanus and continued until the end of the experiment. This treatment caused a significant reduction in the amount of potentiation induced by a $100 \mathrm{~Hz}, 1 \mathrm{sec}$ tetanus, compared with the control condition in the absence of $\mathrm{H}_{2} \mathrm{O}_{2}$ (Fig. 2). $\mathrm{H}_{2} \mathrm{O}_{2}$ had no effect on baseline responses or on levels of post-tetanic potentiation reached immediately after tetanus. Potentiation in the slices exposed to $\mathrm{H}_{2} \mathrm{O}_{2}$ decayed faster after tetanus and reached stable potentiation plateau levels $17.4 \pm 8.5 \%(n=8)$ above baseline, which was well below those of the control slices $(54.5 \pm 8.9 \%$; $n=12)$. When the

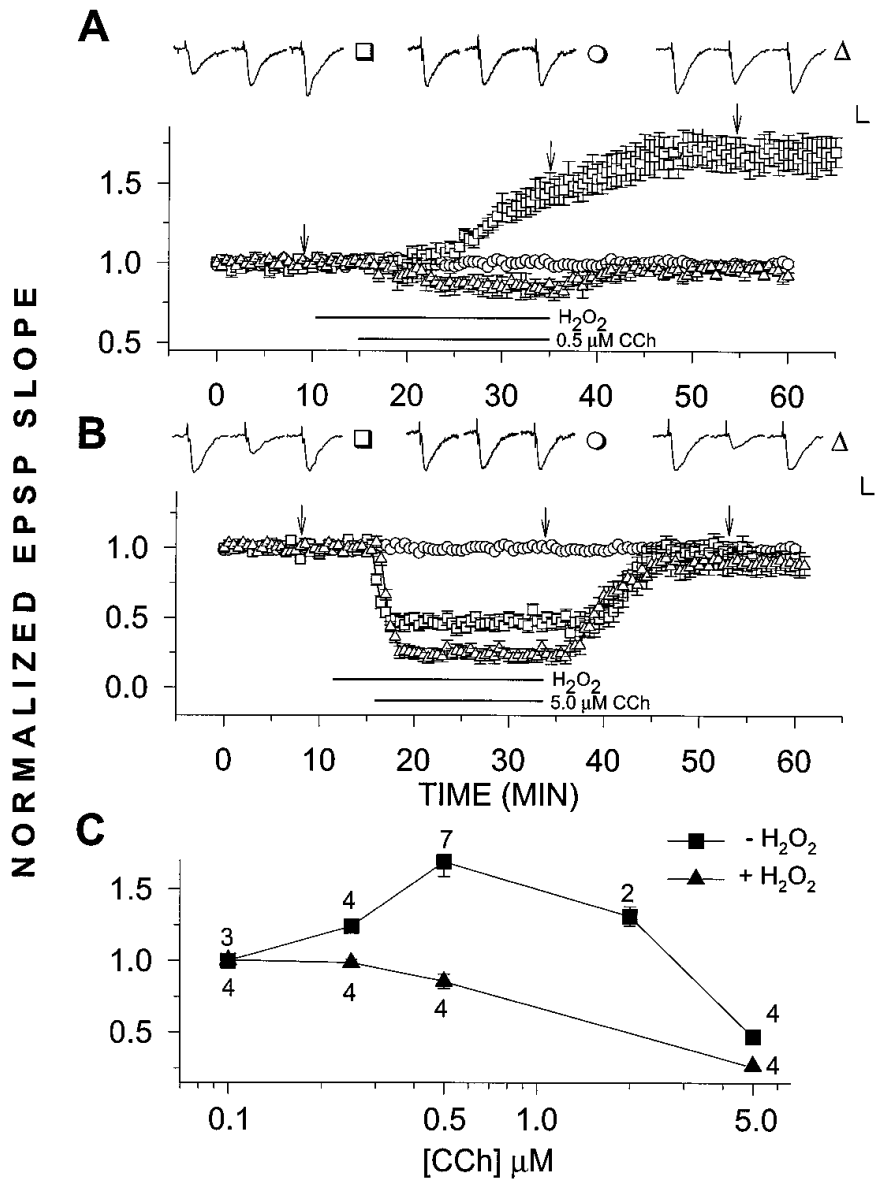

Figure 1. A, $\mathrm{H}_{2} \mathrm{O}_{2}$ selectively blocks $\mathrm{LTP}_{\mathrm{m}} \cdot \mathrm{H}_{2} \mathrm{O}_{2}(29 \mu \mathrm{M})$ applied for 25 $\mathrm{min}$ had no observable effect $(n=4)(\bigcirc)$. However, when applied $5 \mathrm{~min}$ before and together with $\mathrm{CCh}$ for an additional $20 \mathrm{~min}, \mathrm{H}_{2} \mathrm{O}_{2}$ blocked the induction of $\operatorname{LTP}_{\mathrm{m}}(n=4)(\triangle)$. This can be compared with the control case in which $0.5 \mu \mathrm{M} \mathrm{CCh}$ alone was added to the slices for $20 \mathrm{~min}$, resulting in a potentiation of $69.3 \pm 10.2 \%$ above baseline $(n=5)(\square) . B$, $\mathrm{H}_{2} \mathrm{O}_{2}$ did not block the depression of the EPSP slope induced by $5.0 \mu \mathrm{M}$ $\mathrm{CCh}$. As above, $\mathrm{H}_{2} \mathrm{O}_{2}$ alone had no observable effect $(n=4)(\mathrm{O})$. CCh $(5.0 \mu \mathrm{M})$ alone reduced the EPSP slope values to $47.4 \pm 3.3 \%$ of baseline $(n=4)(\square)$, whereas addition of $29 \mu \mathrm{M} \mathrm{H}_{2} \mathrm{O}_{2}$ with $5.0 \mu \mathrm{M} \mathrm{CCh}$ increased the CCh-induced depression, reducing the EPSP slope to $27.2 \pm 4.4 \%$ of baseline values $(n=4)(\triangle)$. $C$, Dose-response relations for increasing concentrations of CCh in $\mathrm{H}_{2} \mathrm{O}_{2}$ clearly shows that although $\mathrm{LTP}_{\mathrm{m}}$ was abolished, the depressing effects of $\mathrm{CCh}$ were present. In this and the following graphs, representative EPSPs are presented above the grouped data. Each EPSP triplet is from one treatment, as identified by the symbol to the right of the triplet. Each individual EPSP within the triplet was sampled at a time corresponding to the arrows or lower case letters in the graph. Calibration, $0.5 \mathrm{mV}, 5 \mathrm{msec}$. Error bars represent SEM, when larger than the symbol. The bars under the graphs designate the duration of drug application.

potentiation in the presence of $\mathrm{H}_{2} \mathrm{O}_{2}$ was subtracted from the control group, it appeared that $\mathrm{H}_{2} \mathrm{O}_{2}$ blocked a slow onset LTP.

A non-NMDA receptor-mediated LTP can be induced in area CA1 of the hippocampus in the presence of the NMDA antagonist 2-APV by application of repeated strong tetani $(200 \mathrm{~Hz})$ to the Schaffer collaterals (Grover and Teyler, 1990; Çavus and Teyler, 1996) (Fig. 3). This type of LTP has been attributed to $\mathrm{Ca}^{2+}$ influx through voltage-gated calcium channels. It is different from NMDA-mediated LTP in that it develops slowly over a period of 20-30 min after tetanus. We induced NN-LTP in the presence of $25 \mu \mathrm{M} 2$-APV by applying three successive tetani (at 


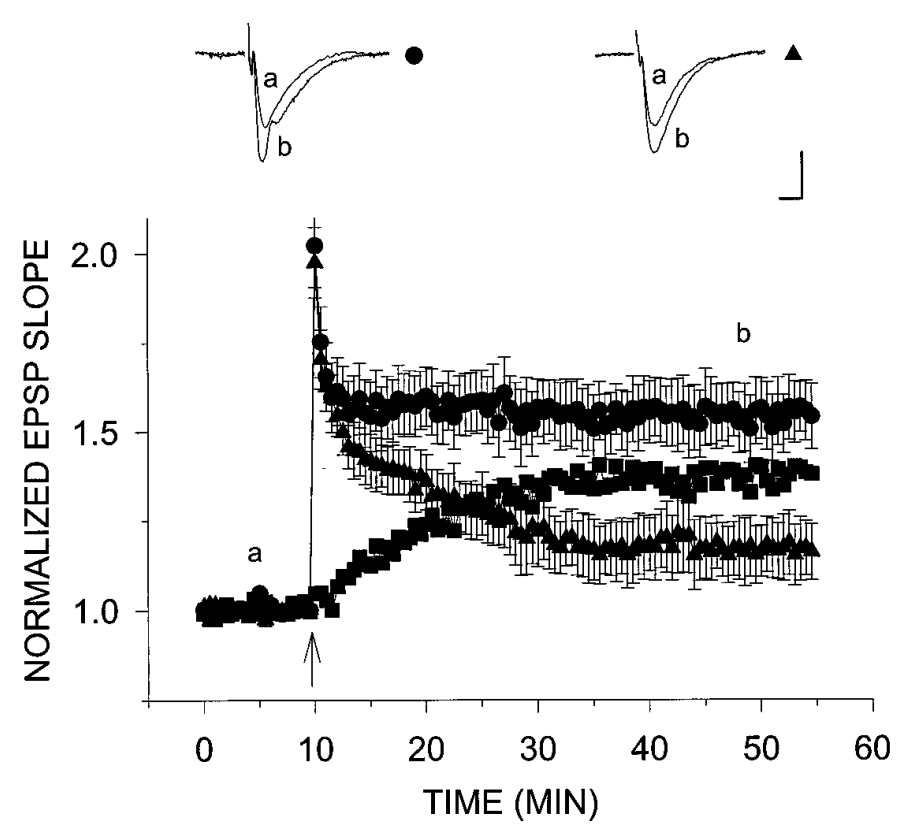

Figure 2. $\mathrm{H}_{2} \mathrm{O}_{2}$ reduces the slow component of tetanic LTP. A single tetanus was applied at twice the test intensity $10 \mathrm{~min}$ after establishment of stable baseline (arrowhead) to slices from young rats in the presence $(\mathbf{\Delta})$ and absence $(-)$ of $\mathrm{H}_{2} \mathrm{O}_{2} \cdot \mathrm{H}_{2} \mathrm{O}_{2}$ had no effect on the amount of post-tetanic potentiation immediately after the tetanus. However, $\mathrm{H}_{2} \mathrm{O}_{2}$ caused an increased decay in this potentiation, and in its presence the EPSP slope leveled off at $17.4 \pm 8.5 \%$ above baseline $(n=8)(\mathbf{\Lambda})$ compared with levels $54.5 \pm 8.9 \%$ above baseline $(n=12)(\bullet)$ without $\mathrm{H}_{2} \mathrm{O}_{2}$. Subtracting tetanic LTP in the presence of $\mathrm{H}_{2} \mathrm{O}_{2}$ from that in its absence yields the middle curve in the graph (ם). Calibration, $0.5 \mathrm{mV}, 5 \mathrm{msec}$.

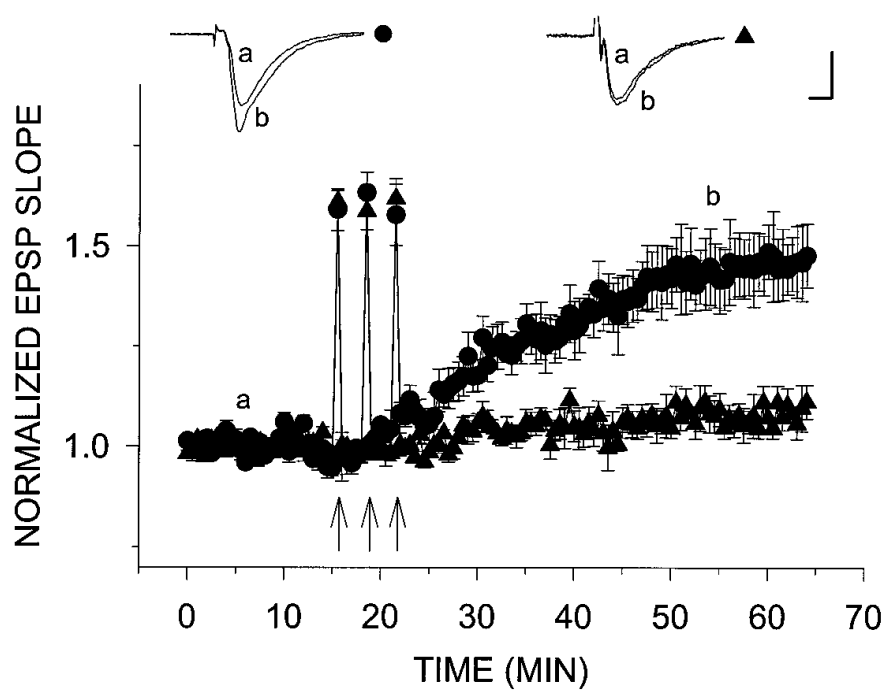

Figure 3. $\mathrm{H}_{2} \mathrm{O}_{2}$ blocks NN-LTP. On induction of NN-LTP by three consecutive $200 \mathrm{~Hz}, 1 \mathrm{sec}$ tetani (arrows), the EPSP slope reached a level of $43.3 \pm 7.3 \%$ above baseline $(n=4)(\bullet)$. The same induction protocol for NN-LTP in the presence of $29 \mu \mathrm{M} \mathrm{H} \mathrm{H}_{2} \mathrm{O}_{2}$ caused only a very slight increase in the EPSP slope $(6.2 \pm 3.4 \% ; n=4)(\mathbf{\Delta})$. The insets above the plots are representative EPSPs sampled at the times indicated by letters $(a)$ and $(b)$ in the graph. Calibration, $0.5 \mathrm{mV}, 5 \mathrm{msec}$.

a frequency of $200 \mathrm{~Hz}) 3 \mathrm{~min}$ apart. Under these conditions, a slow onset potentiation of $43 \pm 7 \%$ above baseline was recorded $(n=4)$. Identical to its effects on $\mathrm{LTP}_{\mathrm{m}}, 29 \mu \mathrm{M} \mathrm{H} \mathrm{H}_{2} \mathrm{O}_{2}$ added to the perfusion medium starting $10 \mathrm{~min}$ before the first of three tetani virtually eliminated NN-LTP (EPSP slope potentiation $6.2 \pm$ $3.4 \%$ above baseline; $n=4$; Fig. 3 ). These results indicate that LTP $_{\mathrm{m}}$ and slow onset NN-LTP share a common mechanism, sensitive to a low concentration of $\mathrm{H}_{2} \mathrm{O}_{2}$.

$\mathrm{H}_{2} \mathrm{O}_{2}$ is normally produced in cells from superoxides $\left({ }^{*} \mathrm{O}_{2}{ }^{-}\right)$, and its concentration is controlled through a balance between production by $\mathrm{CuZn}$-superoxide dismutase and breakdown by peroxidases (De Haan et al., 1995). An imbalance in the synthetic machinery of $\mathrm{H}_{2} \mathrm{O}_{2}$ leads to an increase in ambient $\mathrm{H}_{2} \mathrm{O}_{2}$ in the aged brains (De Haan et al., 1995). We next searched for a change in $\mathrm{H}_{2} \mathrm{O}_{2}$ between slices from young and aged brains. A marked increase in the rate of $\mathrm{H}_{2} \mathrm{O}_{2}$ production in slices from aged rats was found. At two different exposure times after incubation of slices with a fluorescent dye sensitive to $\mathrm{H}_{2} \mathrm{O}_{2}$, the average rate of $\mathrm{H}_{2} \mathrm{O}_{2}$ production was $17.5 \pm 0.80 \mathrm{nmol} / \mathrm{hr}$ per slice in aged slices $(n=8)$ compared with $3.53 \pm 0.60 \mathrm{nmol} / \mathrm{hr}$ per slice in the young slices $(n=8)$.

We compared electrophysiological properties of slices taken from young and aged rats. The baseline slopes of the EPSPs were somewhat slower in the aged rats compared with the young ones $[0.475 \pm 0.036 \mathrm{~V} / \mathrm{sec}(n=10)$ versus $0.611 \pm 0.097 \mathrm{~V} / \mathrm{s}(n=9)$ in the aged versus young slices, respectively; $p>0.05$, two-way $t$ test]. We consistently used a stimulation intensity that produced halfmaximal responses in the control conditions and that allowed the slices of both groups to undergo potentiation to about the same level (seen in the responses to tetanic stimulation; see Fig. 6).

We then examined whether $\mathrm{LTP}_{\mathrm{m}}$ can be induced in aged rat hippocampal slices shown previously to have enhanced production of $\mathrm{H}_{2} \mathrm{O}_{2}$ relative to young controls. CCh $(0.5 \mu \mathrm{M})$-induced $\mathrm{LTP}_{\mathrm{m}}$ was completely absent in four of seven slices prepared from aged rats; in one of seven slices $\mathrm{CCh}$ produced a small, lasting depression of the EPSP slope (to $89.7 \%$ of baseline levels), and in two of seven slices a slight potentiation $(12.7 \pm 2.8 \%$ above baseline) was seen. On average, $0.5 \mu \mathrm{M}$ CCh caused an initial depression followed by a recovery to baseline levels in aged slices (Fig. 4A). This loss of $\mathrm{LTP}_{\mathrm{m}}$ was selective in that no agedependent reduction in the depression of the EPSP slope caused by $5.0 \mu \mathrm{M}$ CCh was seen (Fig. $4 B$ ). The disappearance of $\mathrm{LTP}_{\mathrm{m}}$ cannot reflect the moderate reduction in cholinergic receptor density known to occur with aging (Bartus et al. 1982); however, it may result from an age-related change in second messengers activated by CCh to produce $\mathrm{LTP}_{\mathrm{m}}$ (Auerbach and Segal, 1994).

Parenthetically, the depression caused by high CCh $(5.0 \mu \mathrm{M})$ in aged slices (to $29.4 \pm 9.3 \%$ of baseline) (Fig. $4 B$ ) was similar to the depression caused by high $\mathrm{CCh}$ in normal slices in presence of $\mathrm{H}_{2} \mathrm{O}_{2}(27.2 \pm 4.4 \%$; Fig. $1 B)$. This is contrasted with a depression of only $47.4 \pm 3.3 \%$ caused by the high $\mathrm{CCh}(5.0 \mu \mathrm{M})$ in young slices in the absence of $\mathrm{H}_{2} \mathrm{O}_{2}$ (Fig. $1 B$ ). These results suggest that both the enhanced $\mathrm{CCh}(5.0 \mu \mathrm{M})$-induced depression and the absence of $\mathrm{LTP}_{\mathrm{m}}$ may reflect the higher endogenous levels of $\mathrm{H}_{2} \mathrm{O}_{2}$ in aged slices compared with young slices.

The dose-response profile for CCh effects in slices from aged versus young animals shows that $\mathrm{LTP}_{\mathrm{m}}$ was completely lacking in aged slices and that this was not simply a result of a shift in the dose-response curve (Fig. 5). Furthermore, we have shown previously that LTP $_{m}$ can be induced in young slices by a high concentration of $\mathrm{CCh}(5.0 \mu \mathrm{M})$ if the M3 muscarinic receptor, which mediates the muscarinic depression of the EPSP slope, and GABAergic inhibition are blocked (Auerbach and Segal, 1996). Here we show that in young slices, $5.0 \mu \mathrm{M} C \mathrm{Ch}$ applied in the presence of 4-diphenylacetoxy- $N$-methylpiperidine methiodide (4-DAMP) (an M3 antagonist) and picrotoxin (a GABA antag- 

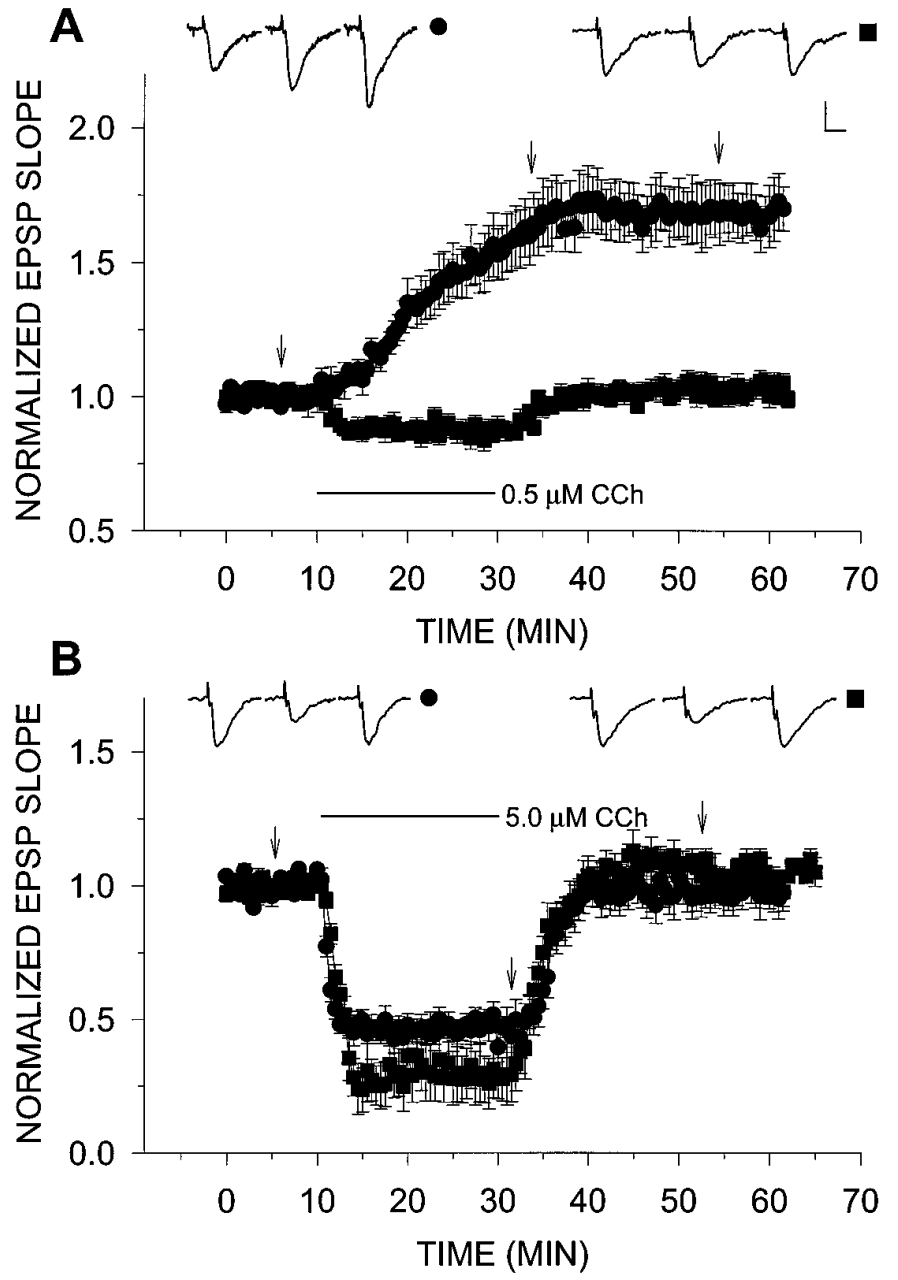

Figure 4. Slices from aged animals lack $\mathrm{LTP}_{\mathrm{m}}$ but express cholinergic depression of EPSP slope. $A$, Addition of $0.5 \mu \mathrm{M}$ CCh to slices from aged rats resulted in a slight initial depression of the EPSP slope, which recovered to baseline levels once the drug was removed from the medium $(n=7)(\square)$. This was compared with $\mathrm{LTP}_{\mathrm{m}}$ in young slices shown here in which $0.5 \mu \mathrm{M}$ CCh potentiated the EPSP slope to $69.3 \pm 10.2 \%$ above baseline $(n=5)(\bullet) . B$, CCh $(5.0 \mu \mathrm{M})$ reduced the EPSP slope in aged slices to $29.4 \pm 9.3 \%$ of baseline values $(n=4)(\square)$ compared with a reduction of $47.4 \pm 3.3 \%$ in young slices $(n=4)(\bullet)$. The insets above the plots are representative EPSPs from single experiments sampled at times indicated by the arrows. Calibration, $0.5 \mathrm{mV}, 5 \mathrm{msec}$.

onist) induced potentiation of $68.6 \pm 8.7 \%$ above baseline $(n=$ $6)$. This level of potentiation is indistinguishable from that induced by $0.5 \mu \mathrm{M} \mathrm{CCh}$ alone in slices from young rats $(69.3 \pm$ $10.2 \% ; n=5$; Fig. 5). However, in slices from aged animals, 5.0 $\mu \mathrm{M} \mathrm{CCh}$ in the presence of 4-DAMP and picrotoxin potentiated the EPSP slope to only $18.1 \pm 12.2 \%$ above baseline $(n=7)$. This is significantly less than the potentiation seen in young slices under the same conditions, indicating that the lack of $\mathrm{LTP}_{\mathrm{m}}$ in aged slices is not attributed to enhanced GABAergic inhibition. The CCh dose-response curve of $\mathrm{CCh}$ in aged slices is similar to that of young slices in the presence of $\mathrm{H}_{2} \mathrm{O}_{2}$ (Fig. 1C).

Tetanic LTP induced by a single $100 \mathrm{~Hz}, 1$ sec tetanus was compared between the two age groups. Immediately after the tetanus, levels of post-tetanic potentiation reached by both the young and aged groups were virtually the same. However, there was a difference in the amount of LTP induced in slices prepared from aged versus young rats (Fig. 6). The EPSP slope measured in

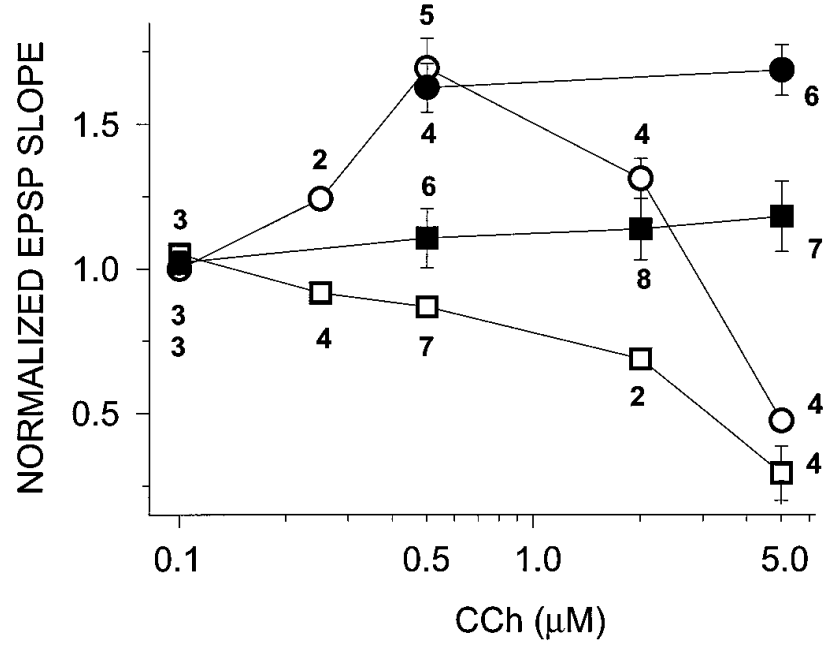

Figure 5. Dose-response curve of effects of $\mathrm{CCh}$ on slices from young $(\mathrm{O}, \bullet)$ and old $(\square, \boldsymbol{\square})$ rats. CCh had a biphasic concentration effect on young slices, i.e., potentiation at low concentrations and depression at high concentrations. Old slices showed only the depression at high $\mathrm{CCh}$ concentrations (empty symbols). The potentiating effects of CCh were completely lacking at all concentrations tested. Slices were also tested in the presence of 4-DAMP and picrotoxin ( filled symbols). Whereas this treatment revealed $\mathrm{LTP}_{\mathrm{m}}$ induction at high CCh concentration $(5.0 \mu \mathrm{M})$ in young slices $(68.6 \pm 8.7 \%)(\bullet)$, only a slight potentiation was seen in aged slices $(18.1 \pm 12.2 \%)(\mathbf{\square})$. The numbers underneath the symbols in the graph correspond to the number of slices tested for each condition.

young slices reached a steady plateau level of $65.9 \pm 7.8 \%$ above baseline $(n=7) 30 \mathrm{~min}$ after tetanus. This is compared with the EPSP slope in old slices, which decayed continuously after tetanus and, in fact, did not reach plateau but reached $34.3 \pm 7.4 \%$ above baseline $(n=6) 30 \mathrm{~min}$ after LTP induction.

The possibility that the difference in late LTP between the young and the aged slices is attributable to NN-LTP was examined. Slices from aged animals had an apparently lower level of expression of NN-LTP, evoked by three trains of tetanic stimulation in the presence of 2-APV, than young slices. Aged slices reached a stable potentiated plateau of $32 \pm 8 \%$ above baseline $(n=8)$, whereas young slices reached potentiated levels of $43 \pm$ $7 \%$ ( $n=4 ; p>0.05$, nonsignificant difference; data not shown).

In aged rats the decrease in tetanic and NN-LTP and the complete absence of $\mathrm{LTP}_{\mathrm{m}}$ can be attributed to cumulative damage stemming from chronic exposure to $\mathrm{H}_{2} \mathrm{O}_{2}$, to some other age-related degenerative process, or to enhanced ambient $\left[\mathrm{H}_{2} \mathrm{O}_{2}\right]$. In the latter case, one should be able to counteract the accumulation of $\mathrm{H}_{2} \mathrm{O}_{2}$ by the administration of exogenous peroxidase. Superfusion with $100 \mathrm{U} / \mathrm{ml}$ catalase for $25 \mathrm{~min}$ had no effect on the EPSP slope recorded in slices from aged $(n=3$; data not shown) and young ( $n=3$; see Fig. 8$)$ animals. In addition, in all slices tested, treatment with $100 \mathrm{U} / \mathrm{ml}$ catalase for $>1 \mathrm{hr}$ and up to $6 \mathrm{hr}$ did not affect their basal reactivity to afferent stimulation. However, on addition of $0.5 \mu \mathrm{M} \mathrm{CCh}$ to catalase-treated, aged slices, $\mathrm{LTP}_{\mathrm{m}}$ was restored (potentiation of $48.6 \pm 8.0 \% ; n=$ 8) (Fig. $7 A$ ). In addition, treatment of aged slices with catalase was sufficient to increase NN-LTP (Fig. $7 B$ ). Catalase elevated NN-LTP in aged slices from $32.2 \pm 8.4 \%(n=8)$ to $58.9 \pm 8.9 \%$ $(n=6)$. When these steady-state potentiation plateau levels were compared across experiments and between groups, this difference was found to be significant ( $p<0.05, t$ test). However, catalase failed to increase levels of $100 \mathrm{~Hz}, 1 \mathrm{sec}$ tetanic LTP $(n=4$; data not shown). 


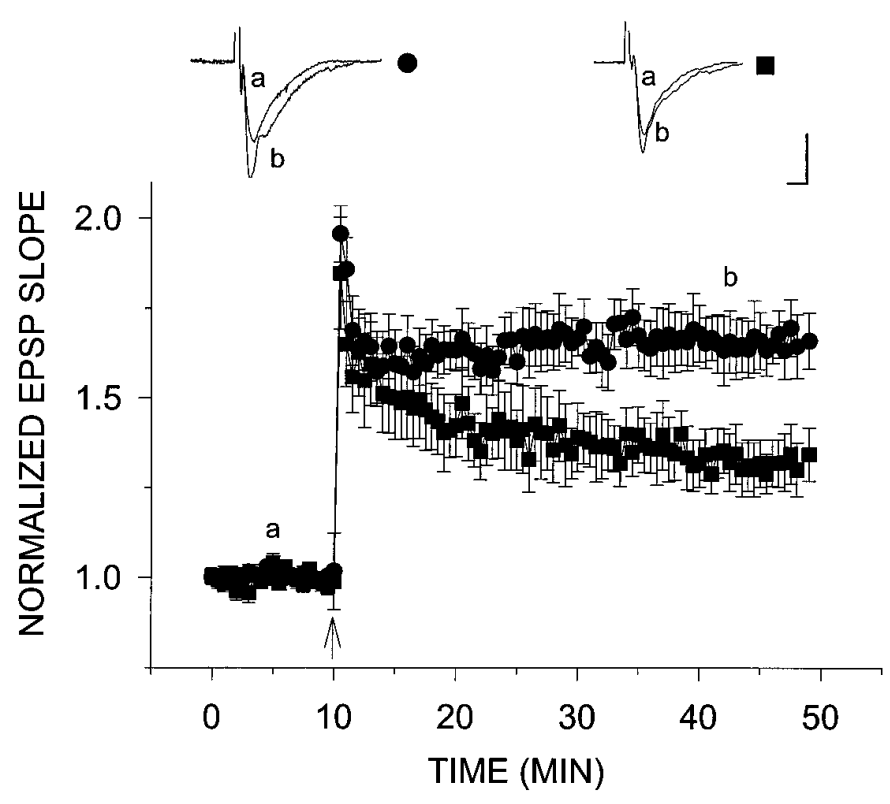

Figure 6. Impairment of tetanic LTP in slices from aged animals. A single tetanus was applied at twice the test intensity $10 \mathrm{~min}$ after establishment of stable baseline (arrowhead) to slices from aged (ם) versus young $(-)$ rats. The amount of post-tetanic potentiation in both groups of slices was similar. Immediately after the tetanus, EPSP slopes from aged slices reached levels $84.7 \pm 15.6 \%(n=6)(\boldsymbol{\square})$ above baseline compared with levels $95.6 \pm 7.8 \%$ above baseline in young slices $(n=7)(\boldsymbol{\bullet})$. However, $30 \mathrm{~min}$ after tetanus, plateau potentiation levels reached in aged slices $(34.3 \pm 7.4 \%)$ were substantially less than those in young slices $(65.9 \pm 7.8 \%)$. Calibration, $0.5 \mathrm{mV}, 5 \mathrm{msec}$.

To test whether endogenously produced $\mathrm{H}_{2} \mathrm{O}_{2}$ can also affect $\mathrm{LTP}_{\mathrm{m}}$ in the young slices, we superfused slices from young rats with $25 \mathrm{U} / \mathrm{ml}(n=4$; data not shown) or $100 \mathrm{U} / \mathrm{ml}$ catalase $(n=$ 3; Fig. 8) for $25 \mathrm{~min}$ and found no effect on the EPSP slope. Slices were also incubated in either catalase concentration for at least 1 $\mathrm{hr}$ in the incubation chamber. Slices were then transferred to the recording chamber and perfused with catalase-containing ACSF. After $10 \mathrm{~min}$ of baseline recording, $0.1 \mu \mathrm{M} \mathrm{CCh}$ was added to the perfusion medium for $20 \mathrm{~min}$. Under these conditions, the slices treated with $25 \mathrm{U} / \mathrm{ml}$ catalase showed a slight reversible potentiation of the EPSP slope, reaching $12.1 \pm 3.9 \%$ above baseline after exposure to $0.1 \mu \mathrm{M} \mathrm{CCh}(n=6)$. Slices treated with 100 $\mathrm{U} / \mathrm{ml}$ showed a stable, long-lasting potentiation, $35.3 \pm 14.3 \%$ above baseline ( $n=4$; Fig. 8). Slices treated with either concentration of catalase for $>1 \mathrm{hr}$ and up to $6 \mathrm{hr}$ showed no effect on their basal reactivity to afferent stimulation. By itself, $0.1 \mu \mathrm{M} \mathrm{CCh}$ did not produce $\mathrm{LTP}_{\mathrm{m}}$ (Fig. 1C).

\section{DISCUSSION}

The present studies demonstrate that low concentrations of $\mathrm{H}_{2} \mathrm{O}_{2}$ can decrease levels of tetanic and NN-LTP, as well as completely block the formation of $\mathrm{LTP}_{\mathrm{m}}$ resulting from exposure to $\mathrm{CCh}$. $\mathrm{H}_{2} \mathrm{O}_{2}$ is formed in normal brain tissue, and its ambient concentration in neurons is kept low primarily by a fast breakdown by glutathione peroxidase (in neurons) or catalase (in many other cell types). $\mathrm{H}_{2} \mathrm{O}_{2}$ can, however, reach high levels in brains of aged animals, owing to a change in the balance between its production and breakdown. The production of $\mathrm{H}_{2} \mathrm{O}_{2}$ is catalyzed by the enzyme $\mathrm{CuZn}$-superoxide dismutase, which is a ubiquitous enzyme. In fact, levels of $\mathrm{H}_{2} \mathrm{O}_{2}$ need not be very high to have an effect. We observe a total suppression of $\mathrm{LTP}_{\mathrm{m}}$ with added $\mathrm{H}_{2} \mathrm{O}_{2}$
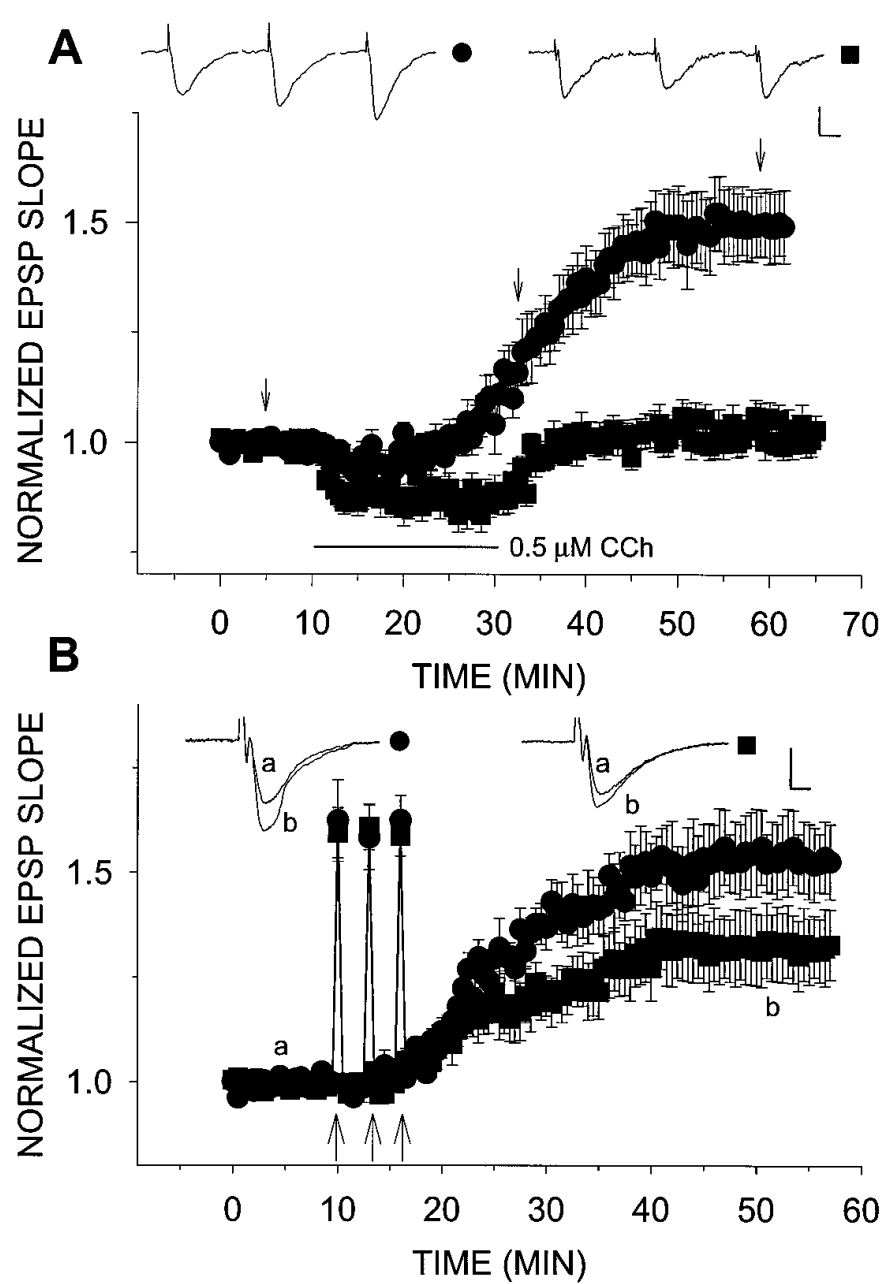

Figure 7. Catalase restores LTP in aged slices. $A, \mathrm{LTP}_{\mathrm{m}}$ is returned to aged slices by treatment with catalase. Slices were incubated in $100 \mathrm{U} / \mathrm{ml}$ catalase $1 \mathrm{hr}$ before and continuously throughout the recording session. Under these conditions, $0.5 \mu \mathrm{M} \mathrm{CCh}$ induced $\mathrm{LTP}_{\mathrm{m}}$ to a level $48.6 \pm 8.0 \%$ above baseline $(n=8)(\bullet)$. This was compared with the lack of effect of $0.5 \mu \mathrm{M} \mathrm{CCh}$ in aged slices in the absence of catalase $(n=7)(\mathbf{\square}) . B$, NN-LTP was elevated by catalase-treated aged slices. The treatment was the same as in $A$. The potentiation in aged slices enabled by catalase increased from $32.2 \pm 8.4 \%(n=8)(\boldsymbol{\square})$ to $58.9 \pm 8.9 \%(n=6)(\bullet)$.

in the micromolar concentration range, which is 20 times lower than doses used by others to observe effects on LTP in the hippocampus (Pellmar et al., 1991). These micromolar concentrations can indeed be reached in the aged brain, as shown previously (Sohal et al., 1994) and as we have also shown here. It is thus possible that overproduction of $\mathrm{H}_{2} \mathrm{O}_{2}$ may underlie the inability of aged brains to express $\mathrm{LTP}_{\mathrm{m}}$. If this is the case, then an acute enhancement of the breakdown of $\mathrm{H}_{2} \mathrm{O}_{2}$ with catalase should reverse the loss of $\mathrm{LTP}_{\mathrm{m}}$ in aged slices, and indeed it does. Although catalase is not likely to cross the cell membrane, $\mathrm{H}_{2} \mathrm{O}_{2}$ flows freely into and out of the cell, and its breakdown by catalase should certainly shift the equilibrium to reduce $\left[\mathrm{H}_{2} \mathrm{O}_{2}\right]$ inside the cell.

The inability of slices from aged animals to produce $\mathrm{LTP}_{\mathrm{m}}$ correlates with deficits in the maintenance of tetanic LTP, as shown here and previously (Barnes, 1994), and deficits in spatial memory seen in aged rats (Buresova et al., 1964; Bartus et al., 1982). $\mathrm{LTP}_{\mathrm{m}}$ is produced within a narrow dose range of $\mathrm{CCh}$ and is likely to be attributed to a change in postsynaptic reactivity to AMPA (Auerbach and Segal, 1996). Also, the inhibitory action of 


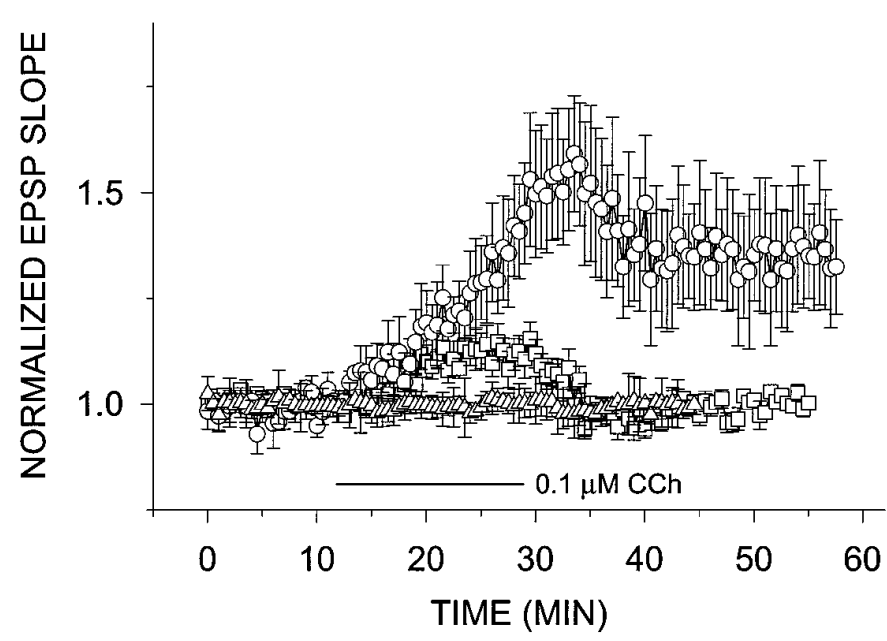

Figure 8. Catalase lowers the threshold for $\mathrm{LTP}_{\mathrm{m}}$ induction in slices from young rats. Slices treated with $25 \mathrm{U} / \mathrm{ml}$ catalase showed a slight potentiation $(12.1 \pm 3.9 \%$ above baseline) of the EPSP slope after exposure to $0.1 \mu \mathrm{M} \mathrm{CCh}(n=6)(\square)$. Slices treated with $100 \mathrm{U} / \mathrm{ml}$ showed a stable, long-lasting potentiation $35.3 \pm 14.3 \%$ above baseline $(n=4)$ (○). Catalase $(100 \mathrm{U} / \mathrm{ml})$ alone added to young slices in the superfusion $10 \mathrm{~min}$ after the establishment of a steady baseline had no effect on evoked response $(n=3)(\triangle)$.

CCh on evoked synaptic responses and other cholinergic effects (Segal, 1982b) are still present in aged brains. These two findings together predict that an attempt to restore muscarinic functions by enhancing the presence of acetylcholine in the synapse (e.g., by blocking ACh esterase) will not be an effective treatment for age-related memory dysfunctions. Instead, a more promising strategy may involve enhancing the ability of the postsynaptic cell of the aged brain to alter oxidative metabolism. The present results also predict that the oxidative damage seen in aged brains may not be irreversible, and readjustment of the oxidative balance may restore cholinergic and perhaps other functions.

The assumed ability of endogenous $\mathrm{H}_{2} \mathrm{O}_{2}$ to block the expression of LTP in aged rats is not the only case in which $\mathrm{H}_{2} \mathrm{O}_{2}$ interferes with neuronal plasticity. We have used recently transgenic mice, made to overexpress the enzyme $\mathrm{CuZn}$-superoxide dismutase ( $\mathrm{CuZn}-\mathrm{SOD})$, which results in overproduction of $\mathrm{H}_{2} \mathrm{O}_{2}$. These mice are also deficient in learning abilities and in expression of sustained LTP. As in the present study, LTP in the $\mathrm{CuZn-SOD}$ mice is enhanced by the addition of catalase, which downregulates the level of $\mathrm{H}_{2} \mathrm{O}_{2}$ (Gahtan et al., 1997). In fact, catalase can also reduce the threshold for $\mathrm{LTP}_{\mathrm{m}}$ in our young slices, indicating that continuous production of $\mathrm{H}_{2} \mathrm{O}_{2}$ may regulate $\mathrm{LTP}_{\mathrm{m}}$ also in the young slice.

One major unresolved issue is what the cellular mechanisms affected by the low concentration of $\mathrm{H}_{2} \mathrm{O}_{2}$ are. Peroxides affect an array of cellular functions, with a major target being protein phosphatases. At higher concentrations (in the submillimolar range), $\mathrm{H}_{2} \mathrm{O}_{2}$ blocks the activity of tyrosine phosphatases, thus enhancing activity of tyrosine kinases (Nakamura et al., 1993; Whisler et al., 1995). These kinases and phosphatases play important roles in regulating $\mathrm{K}^{+}$and other ion selective channels (Levitan, 1994; Holmes et al., 1996). The lack of effect of $\mathrm{H}_{2} \mathrm{O}_{2}$ on the shape or size of the EPSPs recorded in the present studies, as well as the lack of obvious hyperexcitability in the slices, indicate that potassium channels are not the prime target of either $\mathrm{H}_{2} \mathrm{O}_{2}$ or $\mathrm{CCh}$ in our case. We have evidence to indicate that a serine and threonine kinase (Auerbach and Segal, 1994) is critically involved in the generation of $\mathrm{LTP}_{\mathrm{m}}$. However, if $\mathrm{H}_{2} \mathrm{O}_{2}$ blocks phosphatases, it should enhance rather than suppress $\mathrm{LTP}_{\mathrm{m}}$. At any rate, the reported effects of $\mathrm{H}_{2} \mathrm{O}_{2}$ on tyrosine phophatase are exerted at a higher concentration than that needed to block LTP $_{\mathrm{m}}$, and so it is likely that the effect seen here is not mediated by an interaction with protein phosphatases. Another possible site of action is protein kinase $\mathrm{C}$ (PKC), which is reported to be activated by $\mathrm{H}_{2} \mathrm{O}_{2}$ (Whisler et al. 1995). Here again, it is not clear what a persistent calcium-independent activation of PKC will do to kinase-dependent processes related to the muscarinic receptor. Another possible site of action of $\mathrm{H}_{2} \mathrm{O}_{2}$ is perhaps more related to the muscarinic receptor; it has been reported that $\mathrm{H}_{2} \mathrm{O}_{2}$ blocks cholinergic stimulation of AP-1 transcription factor ( $\mathrm{Li}$ et al., 1996), an action that seems to involve phosphoinositide hydrolysis. The muscarinic activation of AP-1 could have been an attractive hypothesis with regard to the site of action of $\mathrm{CCh}$ for the expression of $\mathrm{LTP}_{\mathrm{m}}$, except that it seems to involve M1 rather than M2 receptor, which is the one believed to underlie $\mathrm{LTP}_{\mathrm{m}}$ (Auerbach and Segal, 1996). Thus, the site of action of $\mathrm{H}_{2} \mathrm{O}_{2}$ for its effect on $\mathrm{LTP}_{\mathrm{m}}$ is yet unknown.

One clue to the possible site of action of $\mathrm{H}_{2} \mathrm{O}_{2}$ is the location of the muscarinic $\mathrm{M} 2$ receptor assumed to be activated to produce $\mathrm{LTP}_{\mathrm{m}}$. Although a high concentration of M2 receptors is found on somata of stratum oriens and alveus interneurons, an electron microscopic analysis reveals many M2 immunoreactive dendritic profiles, indicating that these receptors may actually reside on the pyramidal neurons that are directly involved in the production of LTP $_{m}$ (Rouse et al. 1997). This confirms earlier observations suggesting that other M2 responses are present in hippocampal pyramidal neurons (Madison et al. 1987). Thus, the location of the M2 receptor does not provide a clue as to the molecular mechanism associated with the effect of $\mathrm{H}_{2} \mathrm{O}_{2}$ on $\mathrm{LTP}_{\mathrm{m}}$.

The similarities between NN-LTP and $\mathrm{LTP}_{\mathrm{m}}$ in their independence of the activation of the NMDA receptor and the slow time course indicate that they share mechanisms of initiation with the voltage-dependent calcium current (VDCC)-LTP described elsewhere (Çavus and Teyler, 1996). In that study, it is suggested that VDCC-LTP is mediated by a tyrosine kinase, whereas the NMDA-LTP is mediated by a serine and threonine kinase. We were able to verify their results, in that genistein, a tyrosine kinase inhibitor, blocks NN-LTP as well as $\operatorname{LTP}_{\mathrm{m}}$ (J. M. Auerbach and M. Segal, unpublished observations). The effect of $\mathrm{H}_{2} \mathrm{O}_{2}$ on the slow component of the tetanic LTP, as well as the total suppression of NN-LTP and $\mathrm{LTP}_{\mathrm{m}}$, indicates that $\mathrm{H}_{2} \mathrm{O}_{2}$ may indeed act via a tyrosine kinase. On the other hand, $\mathrm{LTP}_{\mathrm{m}}$ is blocked by H7, a general serine and threonine kinase inhibitor (Auerbach and Segal, 1994), so the correlation between the two kinase inhibitors and the LTP types involved may not be straightforward.

One issue, which can be useful in zooming in on the site of action of $\mathrm{H}_{2} \mathrm{O}_{2}$, is the degree of its selectivity; does $\mathrm{H}_{2} \mathrm{O}_{2}$ affect the muscarinic receptor, a second messenger associated with this receptor, or some downstream process shared by a number of stimuli that evoke LTP? Clearly the inhibitory presynaptic muscarinic action is not reduced by $\mathrm{H}_{2} \mathrm{O}_{2}$. On the other hand, a slow onset LTP evoked by repeated tetanic stimulations is also blocked by $\mathrm{H}_{2} \mathrm{O}_{2}$. This indicates that $\mathrm{H}_{2} \mathrm{O}_{2}$ affects a common final path shared by a number of plasticity-producing stimuli. Whatever the exact mechanism, these studies provide a direct link between the cholinergic system, aging, neuronal plasticity, and oxidative metabolism in the brain. 


\section{REFERENCES}

Aniksztejn L, Ben-Ari Y (1991) Novel form of long-term potentiation produced by a $\mathrm{K}^{+}$channel blocker in the hippocampus. Nature 349:67-69.

Auerbach JM, Segal M (1994) A novel cholinergic induction of longterm potentiation in rat hippocampus. J Neurophysiol 72:2034-2040.

Auerbach JM, Segal M (1996) Muscarinic receptors mediating depression and long-term potentiation in rat hippocampus. J Physiol (Lond) 492:479-493.

Barnes CA (1994) Normal aging: regionally specific changes in hippocampal synaptic transmission. Trends Neurosci 17:13-18.

Bartus RT, Reginald L, Dean RL, Beer B, Lippa AS (1982) The cholinergic hypothesis of geriatric memory dysfunction. Science 217:408-417.

Bliss TVP, Lømo T (1973) Long-lasting potentiation of synaptic transmission in the dentate area of the anaesthetized rabbit following stimulation of the perforant path. J Physiol (Lond) 232:331-356.

Bliss TVP, Collingridge GL (1993) A synaptic model of memory: longterm potentiation in the hippocampus. Nature 361:31-39.

Bortolotto ZA, Collingridge GL (1993) Characterisation of LTP induced by the activation of glutamate metabotropic receptors in area CA1 of the hippocampus. Neuropharmacology 32:1-9.

Buresova O, Bures J, Bohdanecky Z, Weiss T (1964) The effect of atropine on learning, extinction, retention and retrieval in rats. Psychopharmacology 5:255-263.

Cathcart R, Schwiers E, Ames BN (1983) Detection of picomole levels of hydroperoxides using a fluorescent dichlorofluorescein assay. Anal Biochem 134:111-116.

Çavus I, Teyler TJ (1996) Two forms of long-term potentiation in area CA1 activate different signal transduction cascades. J Neurophysiol 76:3038-3047.

Coyle JT, Price DL, Delong MR (1983) Alzheimer's disease: a disorder of cortical cholinergic innervation. Science 219:1184-1190.

De Haan JB, Crstiano F, Iannello RC, Kola I (1995) Cu/Zn-superoxide dismutase and glutathione peroxidase during aging. Biochem Mol Biol Int 35:1281-1297.

Doyere V, Laroche S (1992) Linear relationship between the maintenance of hippocampal long-term potentiation and retention of an associative memory. Hippocampus 2:39-48.

Gahtan E, Auerbach JM, Groner Y, Segal M (1997) Reversible impairment of long-term potentiation in transgenic $\mathrm{Cu} / \mathrm{Zn}-\mathrm{SOD}$ mice. Eur $\mathrm{J}$ Neurosci, in press.

Grover LM, Teyler TJ (1990) Two components of long-term potentiation induced by different patterns of afferent activation. Nature 347:477-479.
Holmes TC, Fadool DA, Levitan IB (1996) Tyrosine phosphorylation of the Kv1.3 potassium channel. J Neurosci 16:1581-1590.

Lebrun C, Durkin TP, Marighetto A, Jaffard R (1990) A comparison of the working memory performances of young and aged mice combined with parallel measures of testing and drug-induced activations of septohippocampal and noncortical cholinergic neurones. Neurobiol Aging 11:515-521.

Levitan IB (1994) Modulation of ion channels by protein phosphorylation and dephosphorylation. Annu Rev Physiol 56:193-212.

Li X, Song L, Jope RS (1996) Cholinergic stimulation of AP-1 and $\mathrm{NFkB}$ transcription factors is differentially sensitive to oxidative stress in SH-SY5Y neuroblastoma: relationship to phosphoinositide hydrolysis. J Neurosci 16:5914-5922.

Madison DV, Lancaster B, Nicoll RA (1987) Voltage clamp analysis of cholinergic action in the hippocampus. J Neurosci 7:733-741.

Markram H, Segal M (1992) The inositol 1,4,5-triphosphate pathway mediates cholinergic potentiation of rat hippocampal neuronal responses to NMDA. J Physiol (Lond) 447:513-533.

Molchan SE, Martinez RA, Hill JL, Weingartner HJ, Thompson K, Vitiello B, Sunderland T (1992) Increased cognitive sensitivity to scopolamine with age and a perspective on the scopolamine model. Brain Res Rev 17:215-226.

Nakamura K, Hori T, Sato N, Sugie K, Kawakami T, Yodoi J (1993) Redox regulation of a $s r c$ family protein tyrosine kinase $\mathrm{p} 56^{\text {lck }}$ in $\mathrm{T}$ cells. Oncogene 8:3133-3139.

Pellmar TC, Hollinden GE, Sarvey JM (1991) Free radicals accelerate the decay of long-term potentiation in field CA1 of guinea-pig hippocampus. Neuroscience 44:353-359.

Rossor MN (1982) Neurotransmitters and CNS disease: dementia. Lancet ii: $1200-1203$.

Rouse ST, Thomas TM, Levey AI (1997) Muscarinic acetylcholine receptor subtype M2: diverse functional implications of differential synaptic localization. Life Sci 60:1031-1038.

Segal M (1982a) Multiple actions of acetylcholine at a muscarinic receptor in the rat hippocampal slice. Brain Res 246:77-87.

Segal M (1982b) Changes in neurotransmitter actions in the aged rat hippocampus. Neurobiol Aging 3:121-124.

Sohal RS, Ku H-H, Agarwal S, Forster MJ, Lal H (1994) Oxidative damage, mitochondrial oxidant generation and antioxidant defenses during aging and in response to food restriction in the mouse. Mech Ageing Dev 74:121-133.

Whisler RL, Goyette MA, Grants IS, Newhouse YG (1995) Sublethal levels of oxidant stress stimulate multiple serine/threonine kinases and suppress protein phosphatase in Jurkat T cells. Arch Biochem Biophys 319:23-35 